\title{
各種つべろくりんノ培飬組織發育二及ボス 影響二就テ
}

\section{其Ｉ家鶷胎兒心臟組織二及ボ ス影響}

\author{
京都帝國大學醫學部微生物學敉空（主任 木村敉授）
}

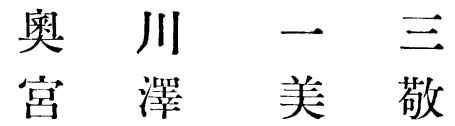

本研究ニ對シテハ帝國學士院ノ補助习得タリ, 茲ニ記シテ以テ謝意ヨ表ス.

\section{【内 容 抄 錄】}

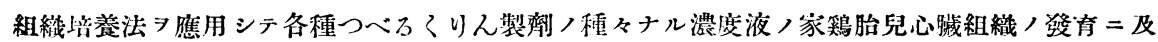

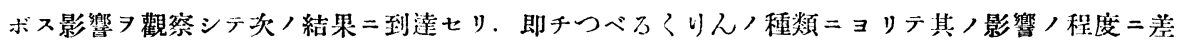

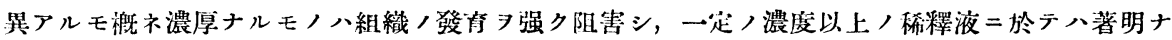
ル影響ヨ及ボサズ。

\section{緒}

第 1 章 實驗方法前實驗材料

第 1 節 組織塔養術式

第 2 節 組織，發有計測
目

粕
第 2 章 實驗成綪

第 3 章 總括並考按

第 4 章 結論

組織培養法ヨ應朋シテつべるくりんノ諸種臟器組織ニ及ボス影響ヨ檢シタル諸業績ノ主ナ ルモノフ述ブレバ次ノ如シ。

1927年 Fischer 八組織培養法ヨ應朋シ鳥型結核菌ヨリ得タルつべるくりんガ結核並二非結

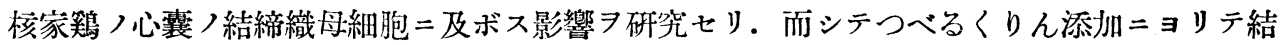

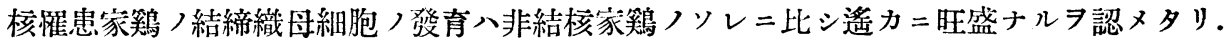

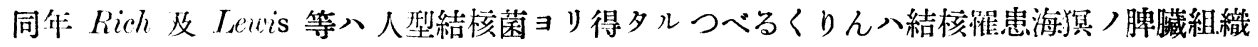
細胞ノ發育增殖ヨ阻止スルニ反シ非核結ノソレニ八何等影響ヨ及バサズト發表セリ・コレニ 相似タル實驗入 1931年 Aronson =ョリテ行ハレタリ. 即人型, 並牛型核結菌ヨリ得夕ル舊

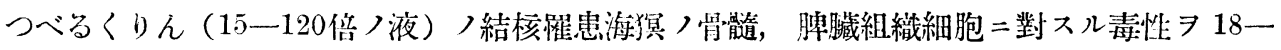
24 時間觀祭七ル ニ對シテハ障害习與へズト論ゼリ.

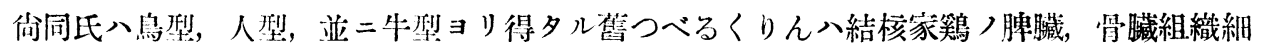


胞ニモ毒性二働キ其ノ發育フ阻害シ非結核家簛ノ夫等ニ八影響ナシト言フ.

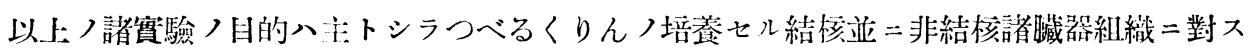
ル感受性〉差異习檢菜七ルモノト言フヨ得ベシ.

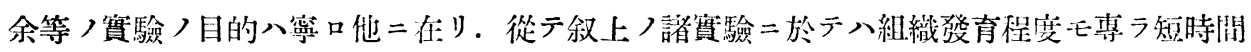

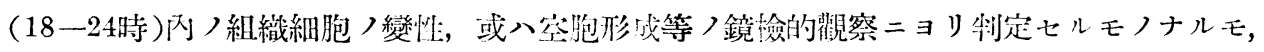

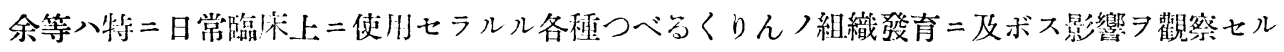
モノニシテ, 其ノ組織發育程度八禁ラ投影機及ぷらにめーたーノ助ヶニョリテ逐日 7 日間= 亘リテ㖕测觀祭セシモノナリ。

\section{第 1 章 賨驗方法並贔驗材料}

\section{第 1 節 組纖培養術式}

組織培養術式八主トシテ Carrel, Fischer ノ方法二從七且缽法二依レリ，其ノ詳納八木村

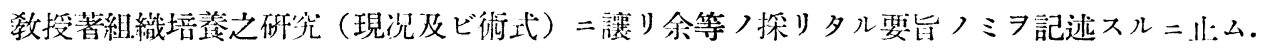

1）供武つべるくりんノ種類.
Alt-Tuberkulin（Koch）（北里研究所製）
Neu-Tuberkulin (Koch)（同
AO (I)
(传鳽研究所製)

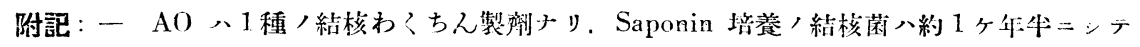

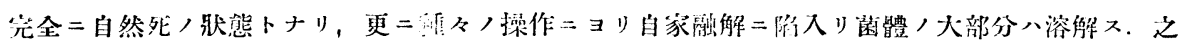

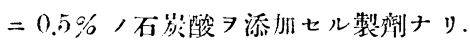

以上 3 種 製劑 7 夫 Tyrode 液二テ $2 \%, 1 \%, 0.2 \%, 0.1 \%, 0.01 \%$ >各稀䆁液トナシ

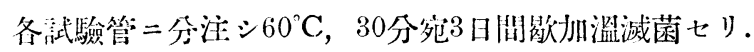

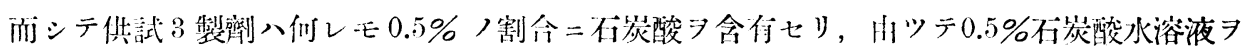

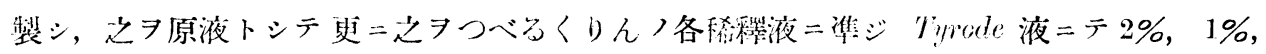

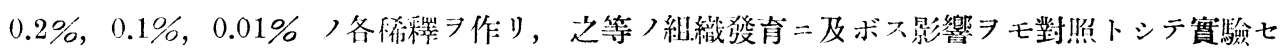
リ.

2) 培黄組織

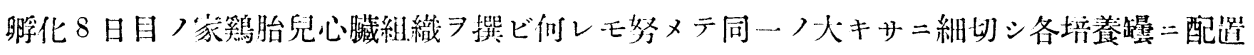
七り.

3）培養基

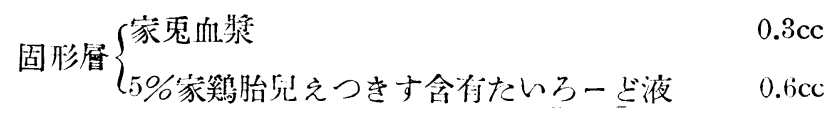




$$
\text { 奥川一三, 宮 罯 美 敬 遮 }
$$

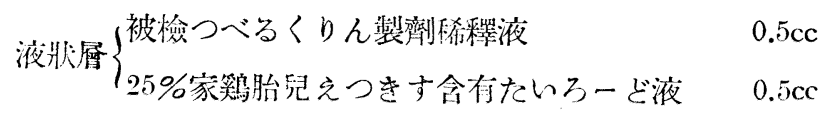

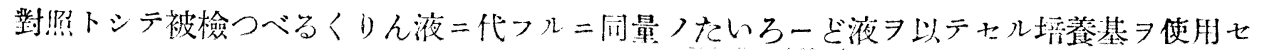
リ。

\section{第 2 節 組織，發育計测}

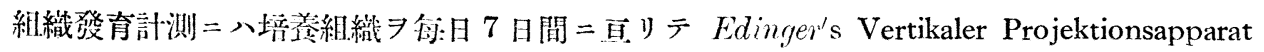

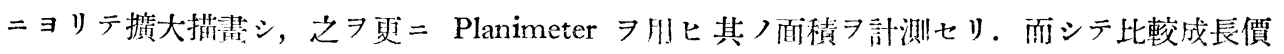

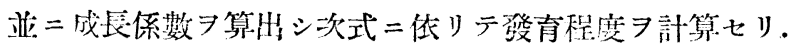

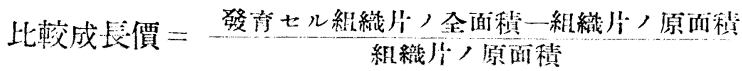

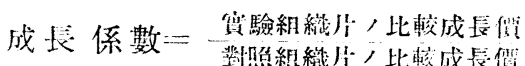

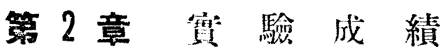

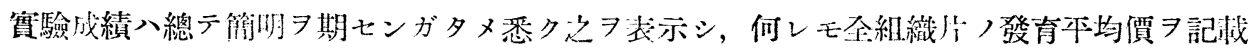

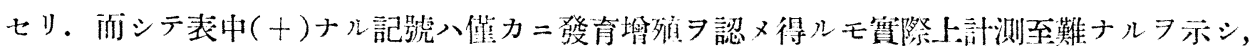
全ク墢育ヨ認メザルモノヨ(0) 馀示セリ。

第 1 表 萿つべるくりんノ影響

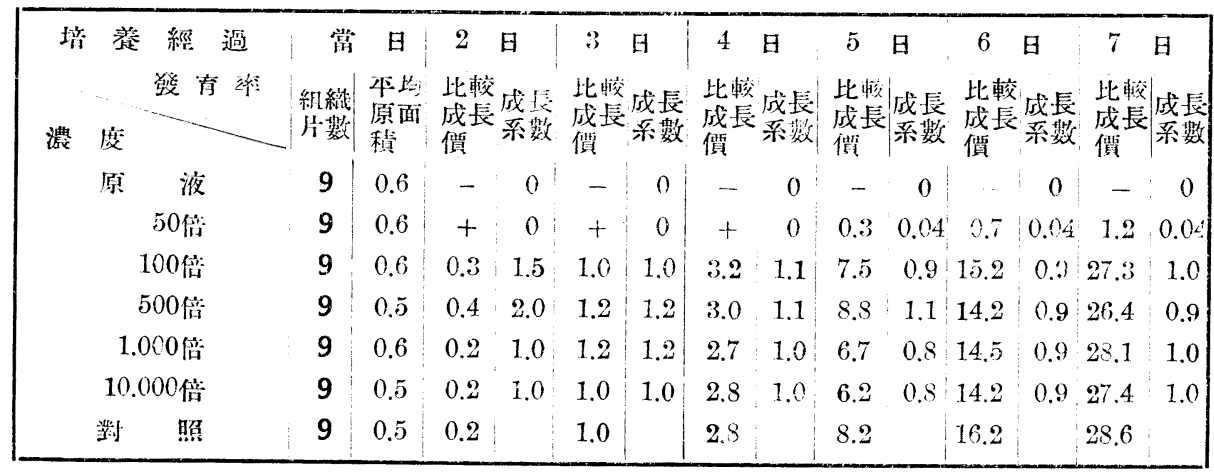

第 2 表 新つべるくりんノ影㴓 


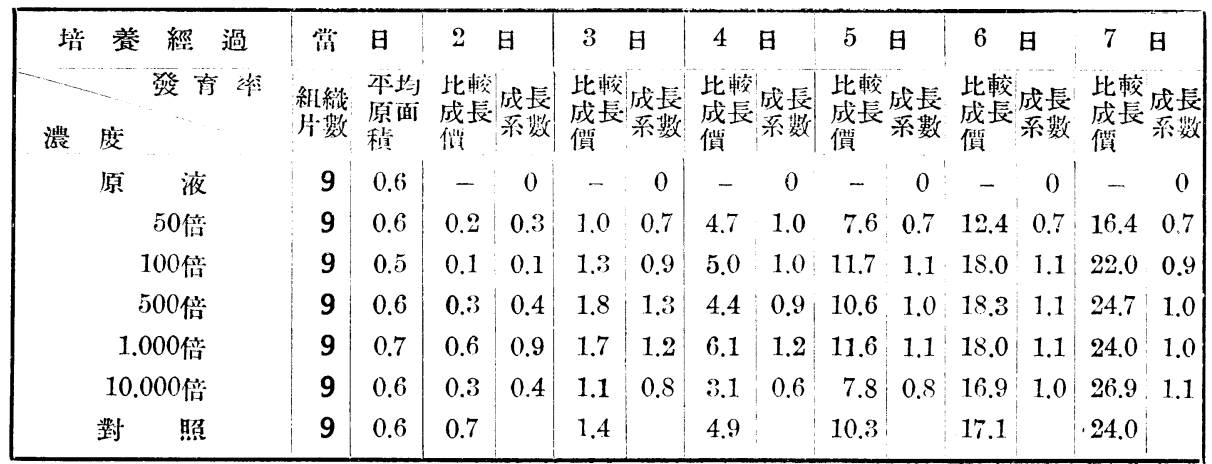

第 3 表 $\mathrm{AO}$ (1號) ノ影響

\begin{tabular}{|c|c|c|c|c|c|c|c|c|c|c|c|c|c|c|c|}
\hline 培 & 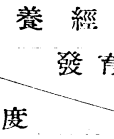 & 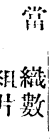 & $\begin{array}{l}\text { 日 } \\
\text { 平均 } \\
\text { 原面 } \\
\text { 栍 }\end{array}$ & $\begin{array}{c}2 \\
\text { 比䡆 } \\
\text { 成長 } \\
\text { 價 }\end{array}$ & $\begin{array}{l}\text { 成長 } \\
\text { 系敕 }\end{array}$ & $\begin{array}{c}3 \\
\text { 此較 } \\
\text { 成長 } \\
\text { 储i }\end{array}$ & $\begin{array}{l}\text { 日 } \\
\text { 成長 } \\
\text { 系數 }\end{array}$ & $\begin{array}{c}4 \\
\text { 些較 } \\
\text { 威長 } \\
\text { 俔 }\end{array}$ & 成長 & $\begin{array}{c}5 \\
\text { 比較 } \\
\text { 成長 } \\
\text { 價 }\end{array}$ & $\begin{array}{l}\text { 日 } \\
\text { 成長 } \\
\text { 系數 }\end{array}$ & \begin{tabular}{|l}
\multicolumn{1}{c}{6} \\
比較 \\
成長 \\
橮
\end{tabular} & $\begin{array}{l}\text { 成長 } \\
\text { 系數 }\end{array}$ & $\begin{array}{c}7 \\
\text { 比較 } \\
\text { 成長 } \\
\text { 曙 }\end{array}$ & 成 \\
\hline & 原 液 & 9 & 0.6 & + & 0 & 0.2 & 0.1 & 0.3 & 0.06 & 0.4 & 0.04 & 0.5 & 0.03 & 0.6 & 0.03 \\
\hline & 50 倍 & 9 & 0.6 & 0.3 & 0.4 & 0.9 & 0.6 & 2.1 & 0.4 & 5.5 & $0 . \bar{j}$ & 9.0 & 0.5 & 17.5 & 0.7 \\
\hline & 100倍 & 9 & 0.7 & 0.3 & 0.4 & 1.2 & 0.9 & 4.5 & 0.9 & 10.0 & 1.0 & 14.5 & 0.8 & 23.5 & 1.0 \\
\hline & 500 倍 & 6 & 0.5 & 0.4 & 0.6 & 1.6 & 1.1. & 4.8 & 0.9 & 10.0 & 1.0 & 18.5 & 1.1 & 25.2 & 1.1 \\
\hline & 1.000 倍 & 9 & 0.6 & 0.5 & 0.7 & 1.1 & 0.8 & 4.2 & 0.9 & 9.4 & 0.9 & 14.8 & 0.9 & 22.9 & 1.0 \\
\hline & 10.000倍 & 9 & 0.7 & 0.3 & 0.4 & 1.6 & 1.1 & 5.0 & 1.0 & 11.3 & 1.1 & 18.0 & 1.1 & 24.6 & 1.0 \\
\hline & 照 & 9 & 0.6 & 0.7 & & 1.4 & & 4.9 & & 10.3 & & 17.1 & & 24.0 & \\
\hline
\end{tabular}

第 4 表 不炭酸ノ影響

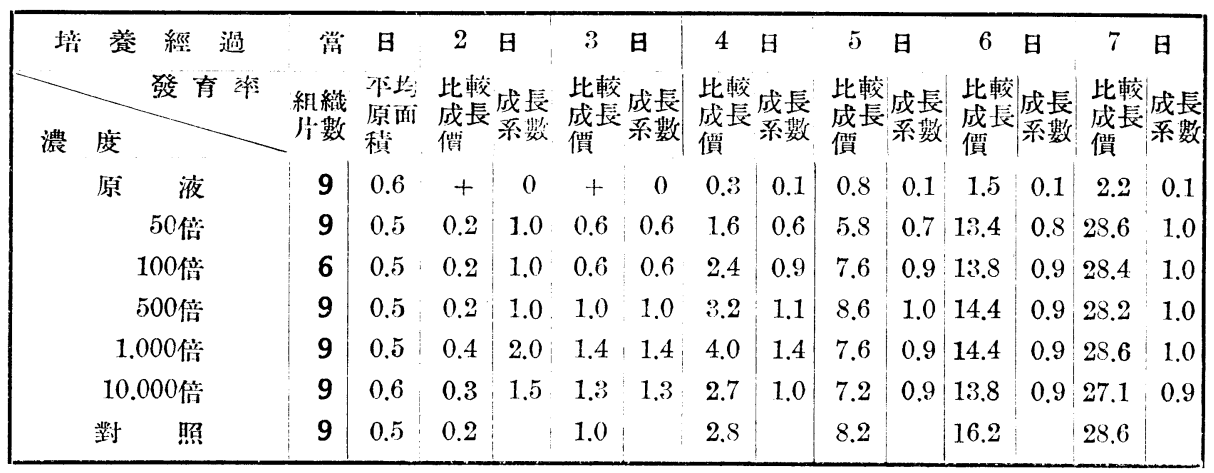

備考： $0.5 \%$ 原液トス

第1一表 7 曲線ニテ示セバ次ノ如シ。但シ $0.2 \% ， 0.1 \% ， 0.01 \%$ ノ曲線八對照ノ曲線二殆 ンド隣接シテ走レリ。ヨツテ各曲線表示ノ混雜习避クルタメ之等习少略シ表つ簡朋习期シタ リ. 
奥 川一三，宮澤 美 敬 述

(1561)
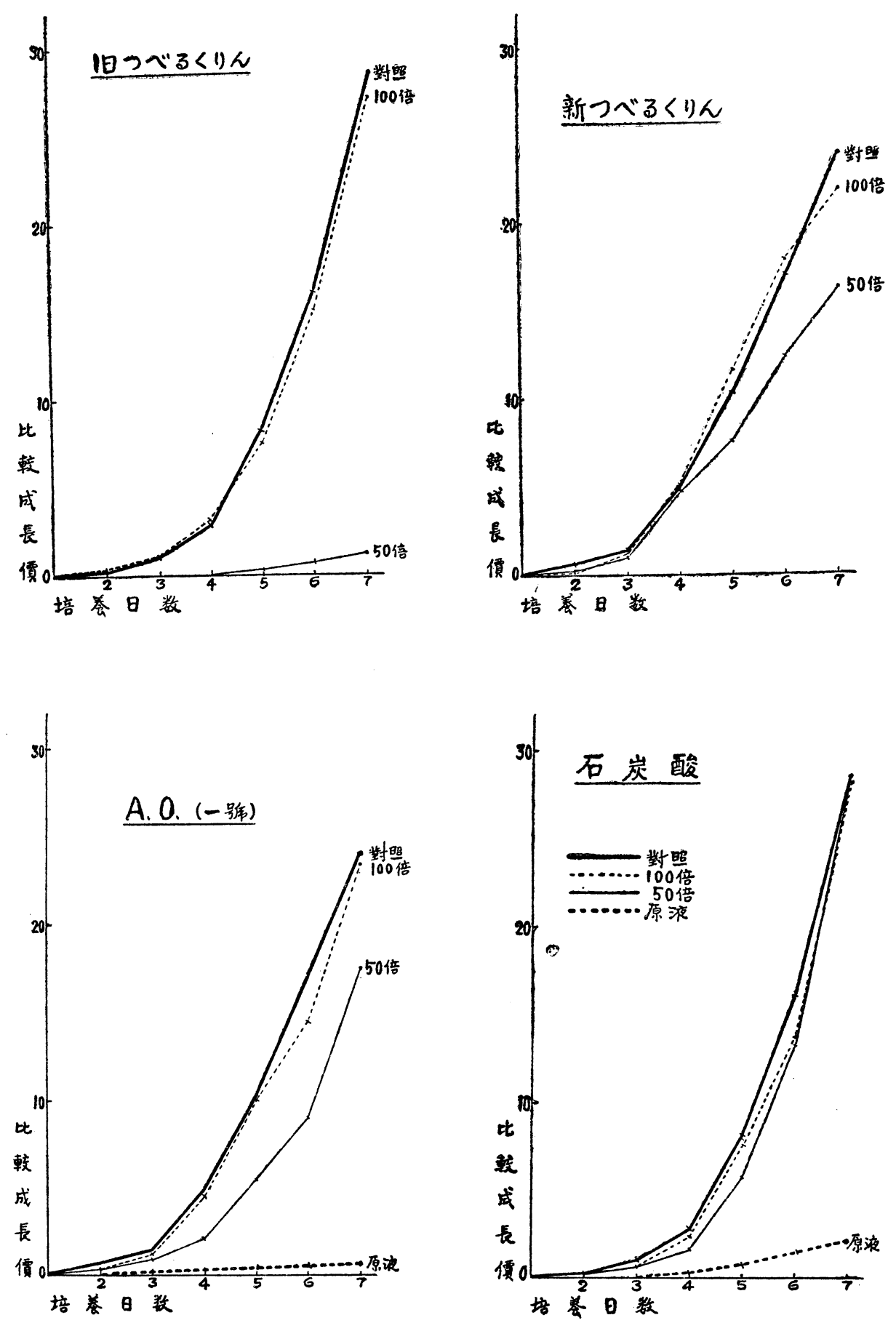


\section{第 3 章 總括並考按}

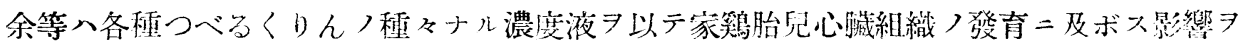
研究七ル二次述〉結果 $习$ 得タリ。

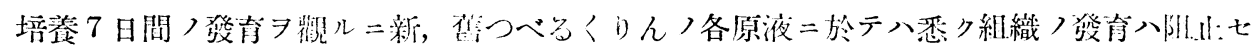
ラレ何レモ終始發育七ズ, AO (I) /原液ニ於テ八第 3 表及第 3 曲線圖二示ス如ク僅微二發 育七ルヨ認メタリ.

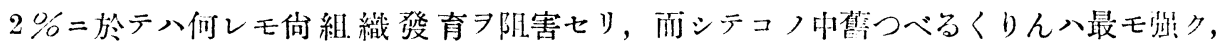
$\mathrm{AO}(\mathrm{J})$ 最モ弱ク發育 $\ni$ 阻川:セリ.

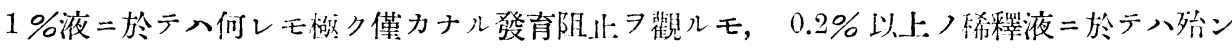
ド影蠁习與へザルモノト見做シテ可ナリ。

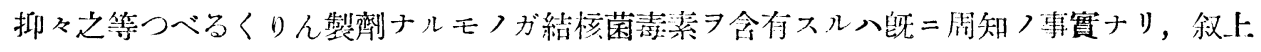

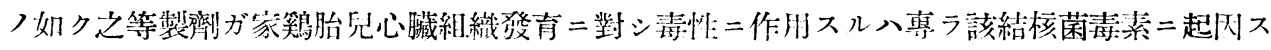

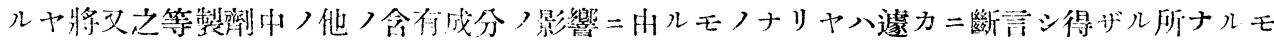

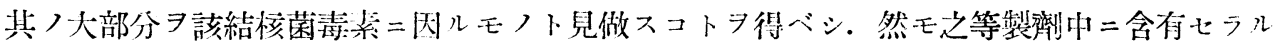
几不炭酸, 影響ノ倠無八當然将滤七ザルベカラサルモノナリ。

第 4 表，第 4 曲線圖二示ス如ク不炭酸原液 $(0.5 \%$ 石炭酸 $)$ 二於テ八發育阴止作川アル・モつべ

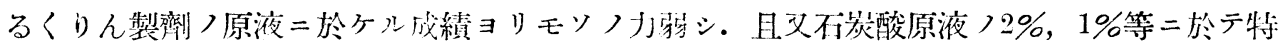

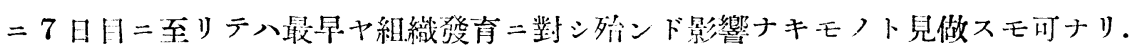

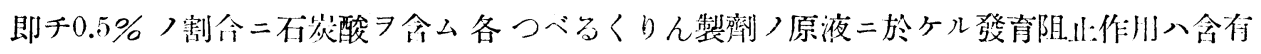

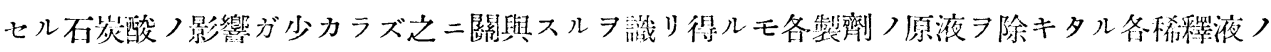

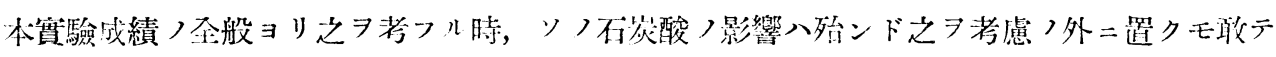
蒵支哭カルベシ.

\section{結論}

組織培養法ニヨレバ各種つベるりん製汶入家第胎兒心臟組織つ發育二對シ，其ノ濃原ナル モノ八弡育ヨ抑制シ・定稀䆁以上ノノ稀釋液ニアリテハ殆ンド影響ヨ與へズ，而シテ舊つべ るくりん八該發育抑制作肞最モ强ク，新つべるくりん及ビ $\mathrm{AO}$ (I) 之二次グ.

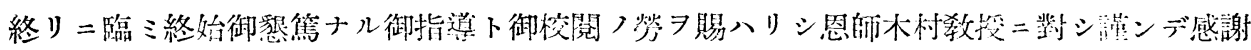
ノ意ヨ表ス。 


\section{各種つバるくりんノ培飬組織發育二及ボス 影響二就テ}

\section{其 II 家鷄胎完脾臟紅織二及ボス影響二就テ}

京都帝國大學醫學部微生物學数空（I:任 木村数授）

$\begin{array}{llll}\text { 奧 } & \text { 川 } & \text { 三 } \\ \text { 宮 } & \text { 簕 } & \text { 美 } & \text { 敬 }\end{array}$

本硐究二對シテハ帝國學士院ノ補助ヨ得タリ，茲ニ記シテ以干謝意ヨ表ス.

\section{【内容抄錄】}

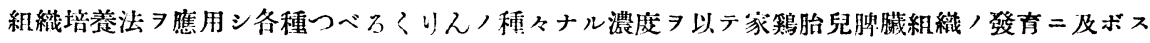

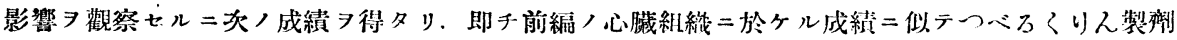

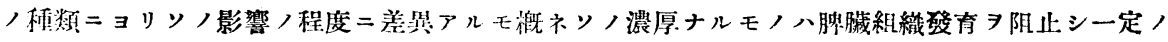

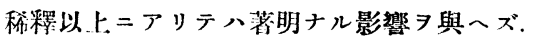

目

緒言

第 1 章 賀驗方法蕜二賽驗材料

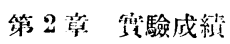

\section{次}

第 3 章 總括亚教按

第 4 章 結 論

主:要交献

\section{緒言}

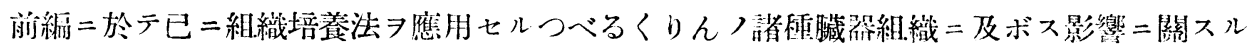
偝潥續ノ主ナルモンタ述ベタリ。

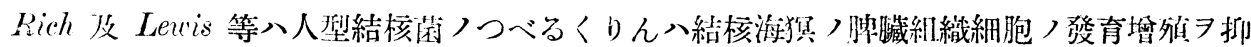

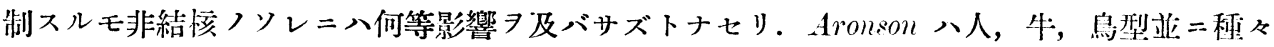

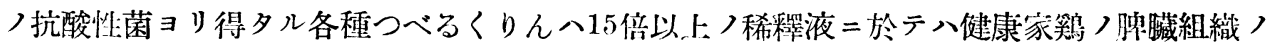
發育ニハ影響ナシト論ゼリ。

佾本邦 =於テモ1932年巽氏八組織唔養法ニョリつべるくりんく結核並二非結核海猽脾臟組 織二及ボス影響二就テ硎究七ル結果つべるくれりんすれるぎーナル現像习證明セリト）簡單 ナル小實驗习報告七ルモ同氏ノ其ノ後つ詳細ナル報告二接七ザルラ遗憾トス。

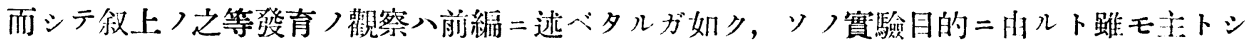

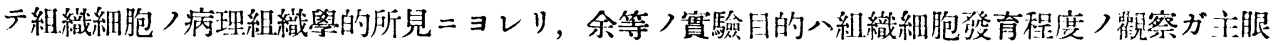

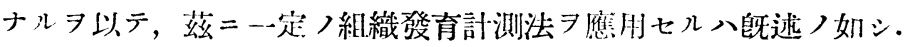

本實驗入前編ニ隼ジ施行七ルモノニシテ，前編ノ實驗成績卜相似タル觀アルモ多少ノ差異 
無キニアラズ，前成績トノ比較對照的ノ意味ヨ含メリ。

\section{第 1 章 實驗方法並二實驗材料}

1) 組織培養術式. 前編/方法=準ズ.

2) つレ゙とくりん製劑.

Alt-Tuberkulin, Neu-Tuberkulin（Koch)（北研）, AO (I)（有馬研）

3) 培善組織

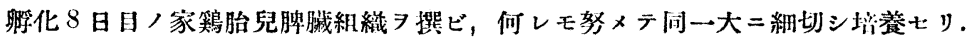

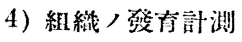

前編ト同沙ク逐日計測セルモ本培養ニ常りテハ 5 日間ニテ打切レリ。蓋シ 6 日以後ニ於テ

八聘臟組織ニアリテハン/發有計測上支障习來タシ誤差ヨ生シ易キガタメナリ。

\section{第 2 章 實 驗 成 綪}

實驗成績八前螎ト同ジク表示シ簡明

第 1 表 霓つべるくりんノ影響

\begin{tabular}{|c|c|c|c|c|c|c|c|c|c|c|c|}
\hline 培 & $\begin{array}{l}\text { 養 經 過 } \\
\text { 發有站 } \\
\text { 度 }\end{array}$ & $\begin{array}{l}\text { 蹈 } \\
\text { 組織 } \\
\text { 战數 }\end{array}$ & $\begin{array}{l}\text { 日 } \\
\text { 本均 } \\
\text { 原面䅡 }\end{array}$ & $\begin{array}{c}2 \\
\text { 比 䡥 } \\
\text { 成長價 }\end{array}$ & $\begin{array}{l}\text { 日 } \\
\text { 成長 } \\
\text { 系數 }\end{array}$ & $\begin{array}{c}3 \\
\text { 比 較 } \\
\text { 成長價 }\end{array}$ & $\begin{array}{l}\text { 日 } \\
\text { 成長 } \\
\text { 系數 }\end{array}$ & $\begin{array}{l}\quad 4 \\
\text { 比 較 } \\
\text { 成長價 }\end{array}$ & $\begin{array}{l}\text { 日 } \\
\text { 成長 } \\
\text { 系數 }\end{array}$ & \begin{tabular}{l}
5 \\
\multicolumn{2}{c}{5} \\
比 較 \\
成長價
\end{tabular} & $\begin{array}{l}\text { 日 } \\
\text { 威長 } \\
\text { 系數 }\end{array}$ \\
\hline & 原 液 & 6 & 0.6 & - & 0 & - & 0 & - & 0 & - & 0 \\
\hline & 50倍 & 9 & 0.6 & 0.4 & 0.1 & 1.3 & 0.1 & 3.7 & 0.2 & 6.1. & 0.2 \\
\hline & 100倍 & 9 & 0.5 & 3.9 & 1.0 & 10.1 & 1.1 & 20.4 & 1.0 & 29.0 & 1.0 \\
\hline & 500倍 & 9 & 0.6 & 3.6 & 0.9 & 10.5 & 1.0 & 19.4 & 0.9 & 27.3 & 0.9 \\
\hline & 1.000倍 & 9 & 0.7 & 4.6 & 1.2 & 12.0 & 1.1 & 22.7 & 1.1 & 32.0 & 1.1 \\
\hline & 10.000倍 & 9 & 0.5 & 4.0 & 1.1 & 11.8 & 1.1 & 21.2 & 1.0 & 30.8 & 1.0 \\
\hline & 對＼cjkstart照 & 6 & 0.5 & 3.8 & & 10.6 & & 20.6 & & 30.2 & \\
\hline
\end{tabular}

第 2 表 新つべるくりんノ影響

\begin{tabular}{|c|c|c|c|c|c|c|c|c|c|c|c|}
\hline 培 & 羑 經 過 & 常 & 日 & 2 & 日 & 3 & 日 & 4 & 日 & 5 & 日 \\
\hline \multirow[t]{8}{*}{ 濃 } & 發商率 & $\begin{array}{l}\text { 租緎 } \\
\text { 数数 }\end{array}$ & $\begin{array}{l}\text { 布均 } \\
\text { 原面皘 }\end{array}$ & $\begin{array}{l}\text { 毕較 } \\
\text { 成長價 }\end{array}$ & $\begin{array}{l}\text { 成長 } \\
\text { 系數 }\end{array}$ & $\begin{array}{l}\text { 比 較 } \\
\text { 成長價 }\end{array}$ & $\begin{array}{l}\text { 成長 } \\
\text { 系數 }\end{array}$ & $\begin{array}{l}\text { 比, 較 } \\
\text { 成長俔 }\end{array}$ & $\begin{array}{l}\text { 成長 } \\
\text { 系數 }\end{array}$ & $\begin{array}{l}\text { 比 較 } \\
\text { 成長價 }\end{array}$ & 成長 \\
\hline & 液 & 6 & 0.6 & - & 0 & - & 0 & - & 0 & - & 0 \\
\hline & 50倍 & 9 & 0.7 & 2.3 & 0.7 & 6.7 & 0.5 & 16.5 & 0.7 & 24.6 & 0.8 \\
\hline & 100倍 & 9 & 0.7 & 3.2 & 0.9 & 10.6 & 0.8 & 19.9 & 0.8 & 30.1 & 0.9 \\
\hline & 500 倍 & 9 & 0.6 & 3.4 & 1.0 & 12.0 & 0.9 & 20.9 & 0.9 & 31.2 & 1.0 \\
\hline & 1.000倍 & 9 & 0.7 & 3.9 & 1.1 & 12,5 & 1.0 & 22.9 & 1.0 & 30.9 & 1.0 \\
\hline & 10.000倍 & 9 & 0.6 & 3.3 & 1.0 & 11.7 & 0.9 & 23.0 & 1.0 & 31.0 & 1.0 \\
\hline & 照 & 6 & 0.6 & 3.4 & & 12.8 & & 23.7 & & 32.3 & \\
\hline
\end{tabular}


第 3 表 $\mathrm{AO}$ (I) 八影響

\begin{tabular}{|c|c|c|c|c|c|c|c|c|c|c|c|}
\hline 培 & 養 經 過 & 霄 & 日 & 2 & 日 & 3 & 日 & 4 & 日 & 5 & 日 \\
\hline 濃 & 度 & $\begin{array}{l}\text { 組織 } \\
\text { 仵数 }\end{array}$ & $\begin{array}{l}\text { 平均 } \\
\text { 原面橉 }\end{array}$ & $\begin{array}{l}\text { 皆校 } \\
\text { 成長傮 }\end{array}$ & 咸長 & $\begin{array}{l}\text { 些慗 } \\
\text { 成長償 }\end{array}$ & $\begin{array}{l}\text { 成長 } \\
\text { 系數 }\end{array}$ & $\begin{array}{l}\text { 比 } \\
\text { 成長償 }\end{array}$ & $\begin{array}{l}\text { 成長 } \\
\text { 系數 }\end{array}$ & $\begin{array}{l}\text { 比慗 } \\
\text { 成長價 }\end{array}$ & $\begin{array}{l}\text { 威長 } \\
\text { 數 }\end{array}$ \\
\hline & 液 & 9 & 0.6 & 1.0 & 0.3 & 1.7 & 0.2 & 2.7 & 0.1 & 3.8 & 0.1 \\
\hline & 50倍 & 9 & 0.5 & 2.9 & 0.8 & 9.4 & 0.9 & 14.5 & 0.7 & 21.0 & 0.7 \\
\hline & 100倍 & 9 & 0.7 & 3.1 & 0.9 & 11.3 & 1.0 & 20.9 & 1.0 & 29.7 & 1.0 \\
\hline & 500 倍 & 9 & 0.6 & 3.6 & 1.0 & 11.1 & 1.0 & 23.2 & 1.1 & 32.0 & 1.1 \\
\hline & 1.000倍 & 9 & 0.6 & 3.7 & 1.0 & 11.8 & 1.1 & 23.4 & 1.1 & 32.8 & 1.1 \\
\hline & 10.000 倍 & 9 & 0.5 & 3.5 & 1.0 & 12.0 & 1.1 & 23.4 & 1.1 & 32.6 & 1.1 \\
\hline & 照 & 6 & 0.6 & 3.6 & & 11.0 & & 21.8 & & 30.4 & \\
\hline
\end{tabular}

第 4 表 石岑酸入影響

\begin{tabular}{|c|c|c|c|c|c|c|c|c|c|c|c|}
\hline \multirow{2}{*}{\multicolumn{2}{|c|}{ 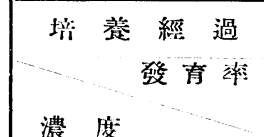 }} & \multicolumn{2}{|c|}{ 㗬 日 } & \multicolumn{2}{|c|}{2 日 } & \multicolumn{2}{|c|}{3 日 } & \multicolumn{2}{|c|}{4 日 } & \multicolumn{2}{|c|}{5 日 } \\
\hline & & $\begin{array}{l}\text { 組織 } \\
\text { 数数 }\end{array}$ & $\begin{array}{l}\text { 平均 } \\
\text { 原面精 }\end{array}$ & $\begin{array}{l}\text { 比較 } \\
\text { 成長儌 }\end{array}$ & $\begin{array}{l}\text { 成長 } \\
\text { 數 }\end{array}$ & $\begin{array}{l}\text { 比較 } \\
\text { 成長偠 }\end{array}$ & $\begin{array}{l}\text { 成長 } \\
\text { 數 }\end{array}$ & $\begin{array}{l}\text { 毕較 } \\
\text { 成長價 }\end{array}$ & $\begin{array}{l}\text { 成長 } \\
\text { 系数 }\end{array}$ & $\begin{array}{l}\text { 比較 } \\
\text { 成長湭 }\end{array}$ & $\begin{array}{l}\text { 盛長 } \\
b^{2}\end{array}$ \\
\hline & 液 & 6 & 0.6 & 0.4 & 0.1 & 1.4 & 0.1 & 2.7 & 0.1 & 4.0 & 0.1 \\
\hline & 50倍 & 9 & 0.6 & 3.6 & 1.1 & 11.9 & 0.9 & 22.0 & 0.9 & 30.3 & 0.9 \\
\hline & 100倍 & 9 & 0.6 & 3.5 & 1.0 & 14.7 & 1.2 & 23.0 & 1.0 & 31.7 & 1.0 \\
\hline & 500 偣 & 9 & 0.5 & 3.2 & 0.9 & 12.3 & 1.0 & 23.2 & 1.0 & 31.1 & 1.0 \\
\hline & 1.000倍 & 9 & 0.6 & 3.5 & 1.0 & 13.5 & 1.1 & 25.4 & 1.1 & 33.0 & 1.0 \\
\hline & 10.000倍 & 8 & 0.7 & 3.9 & 1.1 & 13.4 & 1.1 & 24.9 & 1.1 & 34.4 & 1.1 \\
\hline & 照 & 6 & 06 & 3.4 & & 12.8 & & 28.7 & & 32.3 & \\
\hline
\end{tabular}

備考： $0.5 \%$ 原液トス

\section{第 3 音 總括正考 按}

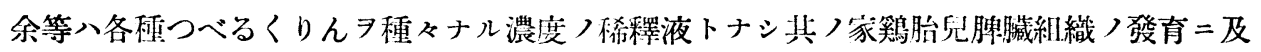
ボス影響 硎究セルニ次述つ如キ結果二到達七り。各種つべるくりん製劑つ影響习培養 5 日 ノ發育ニツキ比較觀察スルニ，新，鹤つべるくりんノ原液二於テハ悉ク組織つ發育八阻止: ラレ終始發育习認メザルモ $\mathrm{AO}(\mathrm{I})$ ノ原液ニアリテハ第 3 表, 第 3 曲線圖二示ス如ク僅微ナ ガラ發育习認メタリ。

$2 \%$ 液ニ於テハ各製劑八侣發育ヨ抑制ス, 就中嚄つべるくりん最モ强シ. 而シテ $\mathrm{AO}(\mathrm{I})$ 最 モ弱シ.

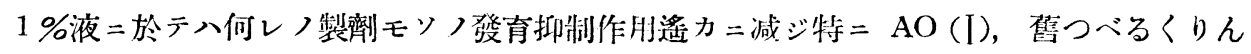
ニ於テハ對照ニ近シ.

$0.2 \%$ 液以上つ稀釋液ニ於テハ著明ナル影響 認メズシテ殆ンド對照ト相違ナシ. 
(1566)

各種つごろくりんノ培羡組織ノ發育二及ボス影警二就テ
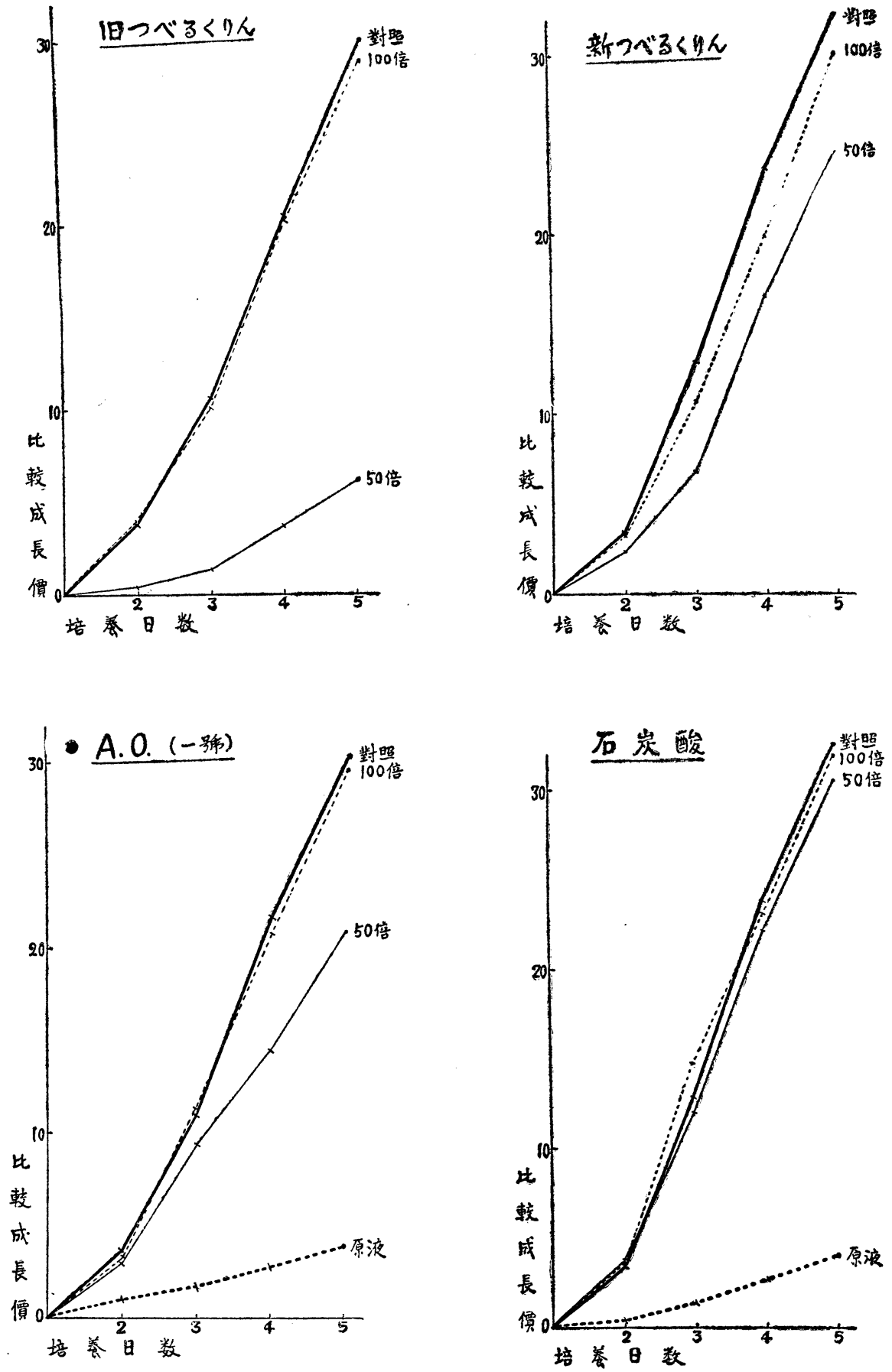


$$
\text { 奧 川一三、宫 澤 美 敬 述 }
$$

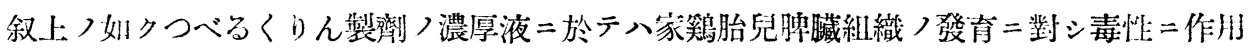

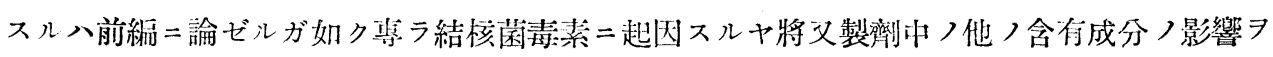
考虑スベキャ八茲二斷言シ難キ所ナルモ本實驗ニ於テモ其組核菌毒素ガ少カラズ關與スルコ トハ疑フベカラザルモノト信ズルモノナリ。

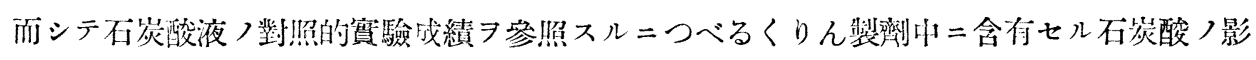

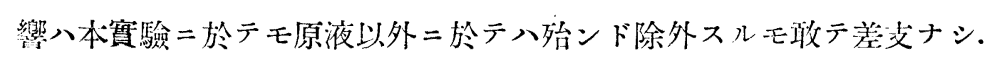

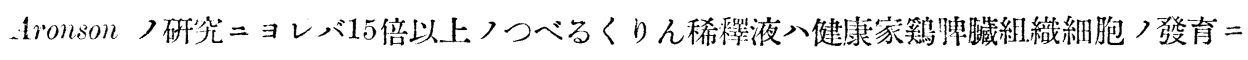

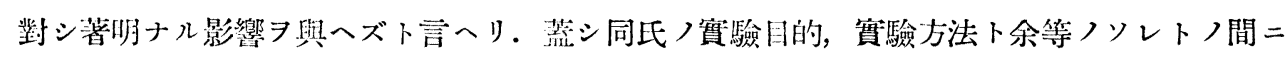
ハ大ナル惩隔ノ存スル所ナリ。例へバ脾臟組織八余等八胎兒ノモノニシテ, 發育觀察時間モ

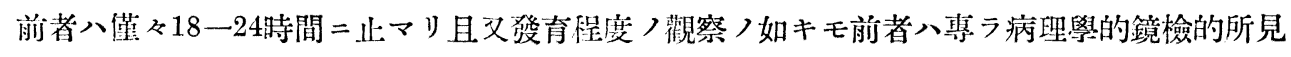
ニ據レルナリ.

份前編つ心藏組織二於ヶル成績卜本實驗成績ノ示ス成䋶トョリ見ルニ,つべるくりん八心

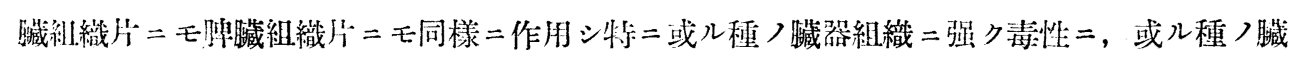
器紬織ニ八弱ク或八無清性二働クガ如キ所謂臟器或ハ組織二對シ選擇的二作用スルガ如キコ トナシ.

\section{第 4 章結猃}

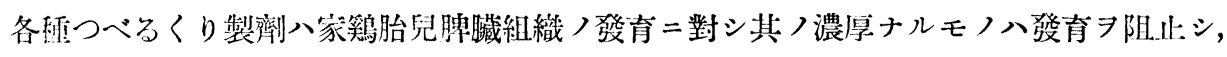

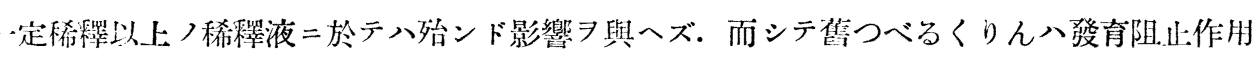
最モ强ク，次デ新つー゙るくりん， $\mathrm{AO}(\mathrm{I})$ )順序ナリ。

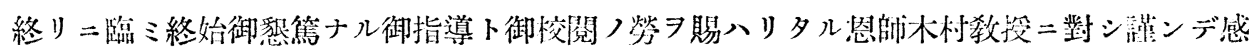
謝〉意

\section{主要 文 献}

1) Aronson, J. D., The Journal of Experimental Medicine 1931 Vọl. 54. P'. 387.

2) Dietrich, w., Deutsche Medizinische Wochenschrift, 1921 Bd. 47. S. $406 . \quad 3)$ 木村

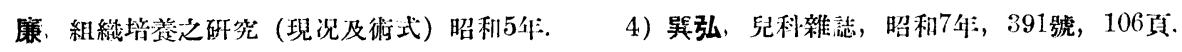

5) 有馬領吉, 絬核10卷，4號，173頁. 6) 植田三郎, 日微生物誌, 25卷, 1207 頁. 